\author{
Лимар В.B. \\ д.е.н., доцент \\ Донецького національного університету імені Василя Стуса \\ ORCID 0000-0002-4328-7529 \\ v.lymar@donnu.edu.ua
}

\title{
ЕЛЕКТРОННА КОМЕРЦІЯ В КОНТЕКСТІ РОЗВИТКУ МІЖНАРОДНОГО РЕКЛАМНОГО МЕНЕДЖМЕНТУ
}

У статті трунтовно проаналізовано наукові підходи до розуміння конщепту електронної комериії, проведено аналіз тенденцій розвитку світового ринку електронної комериї та надано практичні поради щзодо розвитку власного бізнесу в даній сфері. Резюмовано основні риси електронної комериії, зокрема цее: використання електронних платіжних систем у якості аналогу реальних грошових коштів; здійснення угод завдяки використанню сучасних інформачійних технологій; однотипність операцій та можливість вимірів та проведення аудиту провайдером або третьою організацією; права власності та активи зберігаються як у традиційній, так і електронній формах. Структуровано бар'єри для розвитку електронної комериії в Украӥні: обмежений доступ до мережі Інтернет, особливо жителів сільської місиевості; перенасиченість Інтернет-магазинів зайвою інформачією, що провокує втрату потенційних покупиів; недостатньо високий рівень освіченості фахівиів, які праџюють в мережі Інтернет (зокрема відсутність спеціальних знань, необхіднх саме для даної галузі). Розраховано прогноз динаміки світового ринку електронної комериії до 2030 року, який демонструє стійку тенденцію зростання. Представлено практичні поради щуодо ведення бізнесу у галузі електронної комериіі.

Ключові слова: електронна комериія, Інтернет-магазин, електронні платіжні системи, потенційні покупиі, контент, глобальна економіка.

Рис. - 3, Літ. -10

Постановка проблеми. Одним із сучасних напрямків розвитку глобальної економіки є електронна комерція, яка на сьогоднішній день дуже активно розвивається та проникає в усі сфери та галузі життя. Електронна комерція знаходиться на стадії інтенсивного зростання, і ця тенденція ще буде зберігатися протягом майбутнього десятиліття. В попередніх роботах було структуровано види електронної комерції, до яких було віднесено електронний обмін даними, електронні переводи грошових коштів, електронна торгівля, електронні платіжні системи, електронний маркетинг, електронні банківські послуги та електронні страхові послуги.

Сучасна економіка орієнтується на використання новітніх технологій та засвоєння досягнень наукової думки. Новітні ідеї сприяють виникненню нового інформаційного простору, який замінює традиційну економіку. В контексті таких реалій змінюється не лише зміст економічної сторони життя, а й відбуваються зміни у віртуальній реальності.

Аналіз останніх досліджень і публікацій. Електронна комерція як явище отримала дуже швидких темпів розвитку в першу декаду 21 століття. Вона наразі $\epsilon$ 
фокусом наукових інтересів як вітчизняних науковців, так і зарубіжних. В даному дослідженні ми детально проаналізували роботи Козьє Д. [1], Кобелева О.А. [3], Тимакової А.А [4], Калужського М.Л. [6], Ковальова С. [7], Бистрової Н.В. [8]. Також проаналізовано звіти маркетингових агенцій 9-10] щодо динаміки розвитку світового ринку електронної комерції. Далі більш детально представлено аналіз вище зазначених робіт.

Формулювання цілей статті. Метою проведення даного дослідження $\epsilon$ грунтовний аналіз наукових підходів до розуміння концепту електронної комерції, аналіз тенденцій розвитку світового ринку електронної комерції та надання практичних порад щодо розвитку власного бізнесу в даній сфері.

Виклад основного матеріалу. Одним із перших науковців, хто грунтовно почав вивчати явище електронної комерції, є американський економіст Козьє Д. [1]. Він вивчав електронну комерцію на прикладі електронної торгівлі. Козьє Д. зауважує, що основою електронної комерції є традиційна торгівля, однак використання електронних мереж додає їй гнучкість. На додаток вин вважає поняття електронної комерції та електронної торгівлі тотожними. В той же час, наприклад, Климченя Л.С. [2] визначає електронну торгівлю складовою частиною електронної комерції.

Кобелев О.А. вважає електронну торгівлю важливою складовою електронної комерції, визначаючи іiі як “підприємницьку діяльність із здійснення комерційних операцій з використанням електронних засобів обміну даними” [3].

Західні науковці, зокрема Ейморі Д., Голдовскій І. під електронною комерцією розуміють "продаж товарів, при якому як мінімум організація попиту на товари здійснюється через Інтернет" [4]. Пирогов С.В. зауважує, що електронна комерція $є$ “технологією здійснення комерційних операцій та управління виробничими процесами із застосуванням електронних засобів обміну даними" [5].

Так, наведено декілька підходів до визначення поняття електронної комерції однак єдине бачення того, які сфери до неї належать, відсутнє. Зазвичай, вона асоціюється із торгівлею через мережу Інтернет. Більш широким $є$ бачення, що електронна комерція має на увазі будь-яку угоду щодо передачі прав власності або прав користування товарами та послугами, що здійснена через використання електронних засобів комунікації. Особливою рисою таких угод $\epsilon$ тотожність електронних підписів та аналогічних документів на паперових носіях [6].

Як вид діяльності, електронна комерція надає компанії переваги, зокрема за рахунок мінімізації часу та витрат на транспортування. Резюмуємо основні риси електронної комерції:

використання електронних платіжних систем у якості аналогу реальних грошових коштів;

здійснення угод завдяки використанню сучасних інформаційних технологій;

однотипність операцій та можливість вимірів та проведення аудиту провайдером або третьою організацією;

права власності та активи зберігаються як у традиційній, так і електронній формах [7].

Сьогодні широкої популярності набули такі види електронної комерції: торгівля медіа-контентом, надання консультаційних, довідкових послуг, Інтернет - магазини та надання банківських послуг.

Враховуючи сучасні умови розвитку української економіки, можна визначити наступні бар'єри для розвитку електронної комерції в нашій країні:

обмежений доступ до мережі Інтернет, особливо жителів сільської місцевості; 
перенасиченість Інтернет-магазинів зайвою інформацією, що провокує втрату потенційних покупців;

недостатньо високий рівень освіченості фахівців, які працюють в мережі Інтернет (зокрема відсутність спеціальних знань, необхідних саме для даної галузі).

Система управління підприємством, яке займається електронною комерцією, має на увазі широке застосування інформаційних технологій. Їх використання зменшує трансакційні витрати та стандартизує процеси. На додаток запровадження інформаційних технологій сприяе підвищенню інвестиційної привабливості підприємства. Не зважаючи на те, що галузь електронної комерції потребує запровадження інформаційних технологій та інновацій, вони запроваджуються не досить швидкими темпами. Однією із причин повільного запровадження інновацій $\epsilon$ недосконалість організаційних структур підприємства. Як правило, в сучасних підприємствах відсутня позиція, яка була б відповідальної за впровадження нових інформаційних технологій як засобу розвитку бізнесу. Також, повторимо, що не практично відсутні фахівці, підготовлені для роботи саме у сфері електронної комерції [8].

Зазначимо, що не дивлячись на те, що кількість підприємств у сфері електронної комерції зростає, велика кількість із них не доходять до етапу розкриття свого потенціалу. Причинами цього $є$ наступні. По-перше, більшість із підприємств електронної комерції не дають покупцю можливостю повністю здійснити увесь цикл продажу, тобто модель, яку вони пропонують, має спрощений характер. Отже, цикл продажу включає чотири етапи: по-перше, покупці запитують про наявні товари; подруге, вони збирають та порівнюють відповіді; по-третє, клієнт вирішує, здійснювати покупку чи ні; по-четверте, якщо рішення про покупку є позитивним, то наступає останній етам, зокрема формується платіжне доручення та виконання (поставка товару або надання послуги). Так, більшість сайтів не дають відповіді по всім чотирьом етапам. Наприклад, сайт може відповісти на питання щодо продукту, але не відповідати на ти питання, які має на увазі споживач. В інших випадках покупець отримує інформацію про те, де і що він може придбати, але не отримує інформації про те, як можна здійснити оплату.

Друга проблема виникає, коли зусилля не $\epsilon$ інтегрованими в корпоративну організацію. У більшості компаній електронна комерція виступає лише частиною інформаційної системи, а не у якості функціонального бізнес-процесу. I це, на нашу думку, $\epsilon$ основною причиною проблем, тому що працівники, які виготовляють продукцію або надають послуги, не несуть відповідальності за їх реалізацію через Інтернет-магазини. В даному випадку перспективним $\epsilon$ напрямок децентралізації влади, щоб виділити Інтернет-магазини в окрему одиницю бізнесу, щоб працівники, які реалізують товари в Інтернеті, несли відповідальність за свою роботу в межах корпоративної мережі.

Далі представлено найкрупніші ринки електронної комерції в 2020 році (рис. 1).

Як бачимо 3 наведеного рисунку, найбільшими ринками електронної комерції в 2020 році стали ринки Китаю та США із обсягом 672 та 340 млрд. дол. відповідно. Приблизно однаковими за обсягами є ринки Японії та Німеччини (79 та 73 млрд. дол. відповідно), Великобританії, Франції та Південної Кореї (49, 43 та 37 млрд. дол. США), Росії та Бразилії (20 та 19 млрд. дол. США).

В минулому дослідженні вже було структуровано види діяльності, віднесені до сфери електронної комерції, наведемо їх знову:

Інтернет-торгівля (онлайн-магазини); 


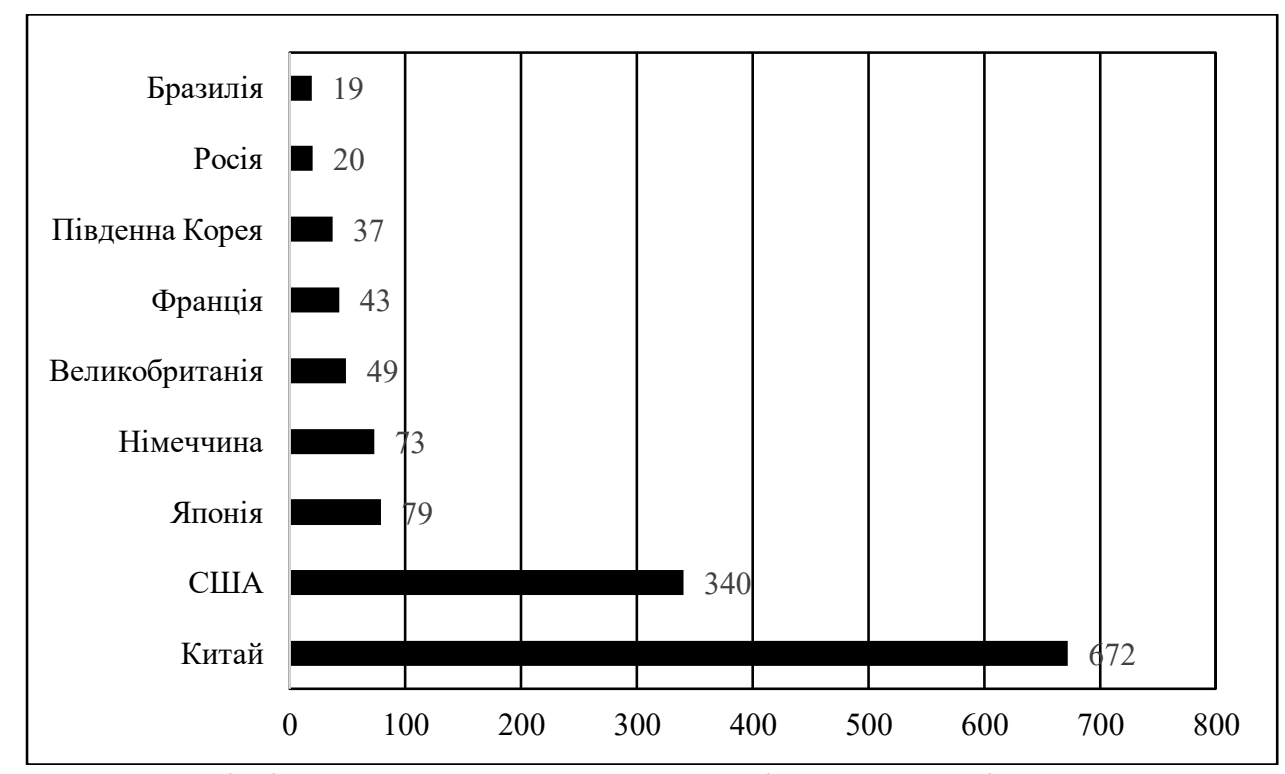

Рисунок 1 - Найкрупніші ринки електронної комерції в 2020 році, млрд. дол. США

Інтернет-торгівля (онлайн-магазини);

електронний обмін інформацією, в тому числі й прості інформаційні сайти;

Інтернет-банкінг та страхування;

Грошові перекази та електронні гаманці;

Збір інформації для створення клієнтської бази [9].

Щодо переваг та недоліків бізнесу у сфері електронної комерції, то вони також розглядалися та структурувалися в минулих дослідженнях, тому наразі детально не будемо на цьому зупинятися, тому ще це не $є$ предметом даного дослідження. Пропонуємо проаналізувати фактори, що стримують розвиток електронної комерції.

1. Невміння працювати в мережі або недостатній рівень освіченості в даній сфері. Процес побудований на принципах обробки замовлень, логістики та аналітики. Відповідати на запити варто своєчасно, щоб не було відтермінування не відобразилося негативно на іміджі компанії. Відповіді із запізненням негативно впливають на рейтинги компанії.

2. Відсутність необхідної нормативно-правової бази, що регламентує діяльність у даній сфері. Особливо це стосується захисту персональних даних, які в реальності $€$ зовсім незахищеними.

3. Дуже висока конкуренція. Пандемія, яка наразі охопила всі сфери життя, внесла свої корективи у ведення бізнесу і на сьогоднішній день практично все можна придбати в Інтернет-магазинах.

4. Недовіра споживачів, яка обумовлена великою кількістю шахрайських дій на просторах Інтернету.

Даний список не $є$ завершеним, він, звісно, є набагато більшим і залежить від конкретного виду електронної комерції, які було структуровано вище. Однак, наведені проблеми є характерними для електронної комерції в цілому.

На наступному рисунку представлено обсяги електронної торгівлі в 2020 році за регіонами світу (рис. 2). 

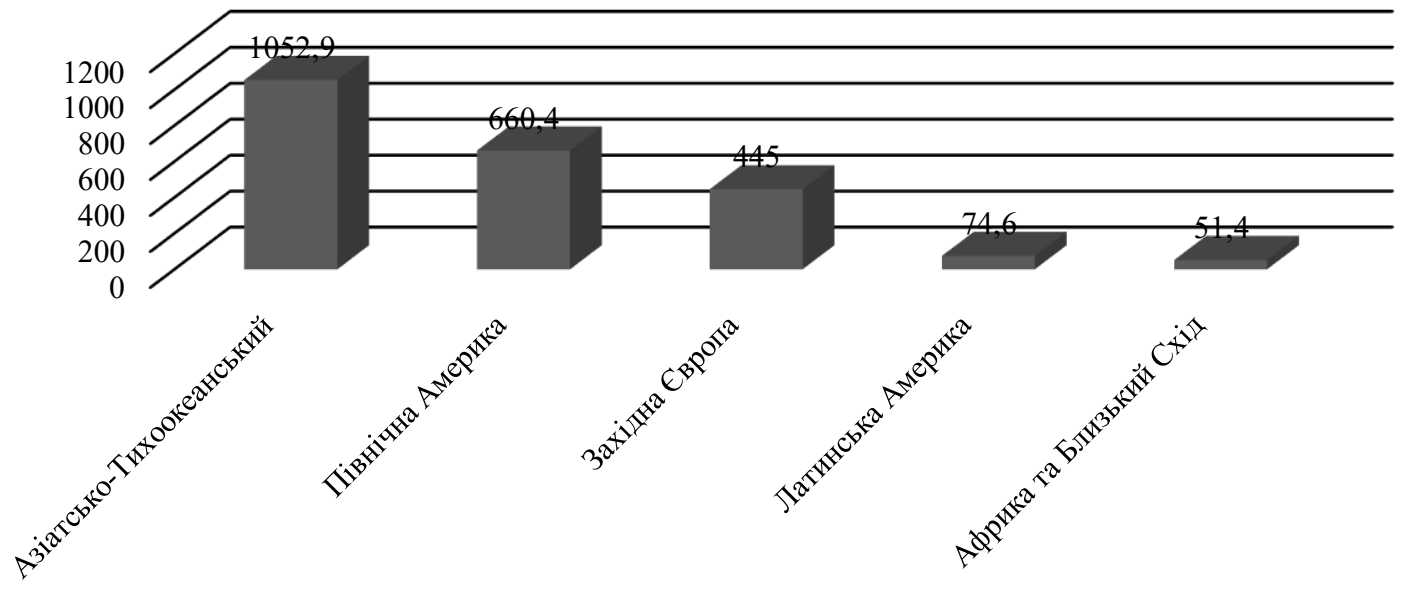

Рисунок 2 - Електронна торгівля в 2020 році в регіональному розрізі, млрд. дол. США [9]

Як бачимо, в регіональному розрізі країни Азіатсько-Тихоокеанського регіону випереджають решту представлених регіонів із показником обсягу ринку електронної комерції 1052,9 млрд. дол. СШ; країни Північної Америки відстають від даного регіону приблизно на 400 млрд. дол. США; на третьому місці- країни Західної Європи і на четвертому та п’ятому місцях країни Латинської Америки та Африки і Близького Сходу відповідно.

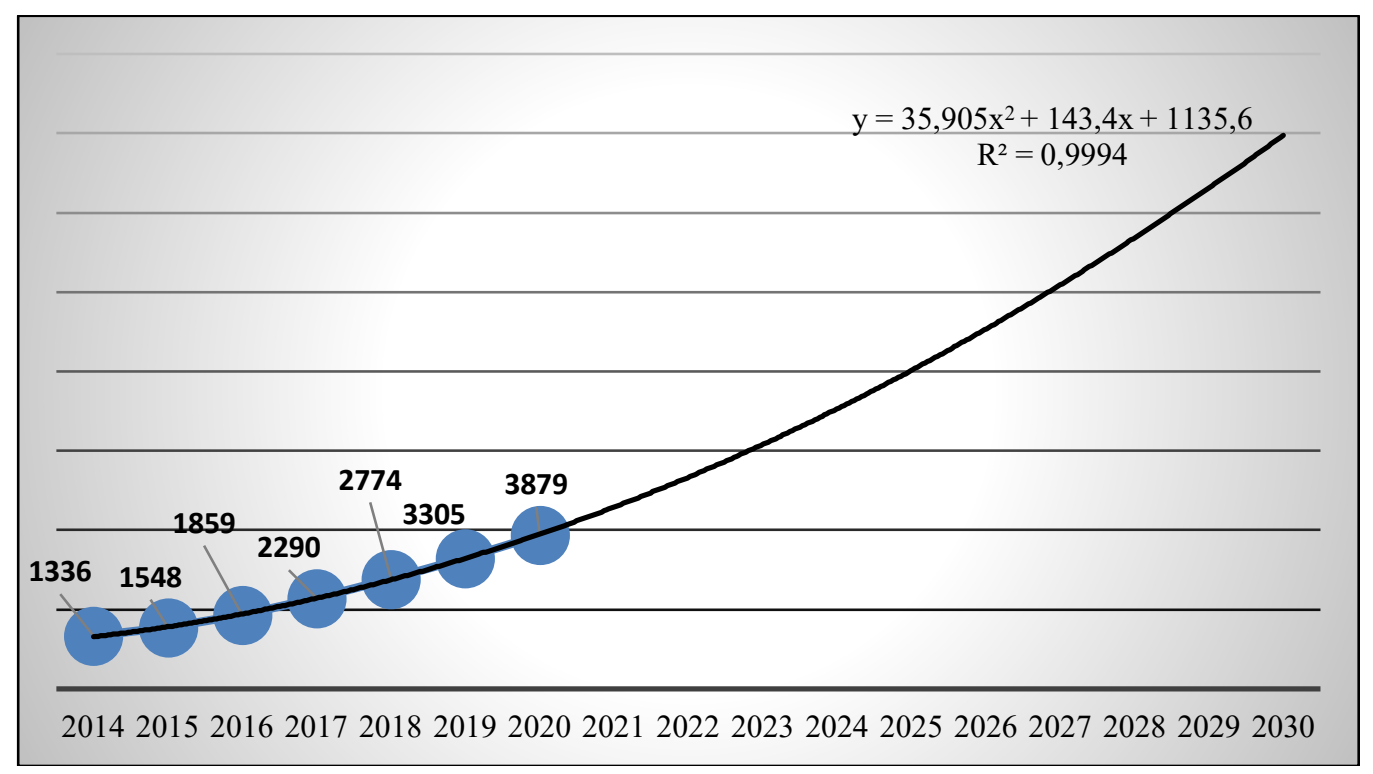

Рисунок 3 - Прогноз зростання світового ринку електронної комерції до 2030 року, млрд. дол. США

Джерело: розраховано автором на основі [10]

На рисунку вище ми бачимо динаміку світового ринку електронної комерції з 2014 до 2020 року, яка демонструє стійку тенденцію зростання. Це дозволяє зробити 
припущення, що така тенденція зберігатиметься і в найближчому майбутньому. Для підтвердження припущення побудовано тренд на базі поліноміальної функції (рівняння наведене на рисунку), при якій $\mathrm{R}^{2}=0,99$. Іншими словами, майже зі 100-відсотковою вірогідністю через 10 років у 2030 році обсяг світового ринку електронної комерції зросте приблизно у 6 разів. Зауважимо, що така тенденція $є$ можливою при відсутності форс-мажорних факторів та криз глобального масштабу.

В попередньому дослідженні було структуровано сфери використання електронної комерції. В даній роботі більш детально на них зупинимося.

Бізнес для підприємництва або В2В має на увазі, що учасниками угоди $\epsilon$ підприємства, дана схема є дуже розповсюдженою. Оптові компанії шукають клієнтів в Інтернеті, а потім реалізують свою продукцію за вигідною для обох сторін ціною. Для здійснення угод використовуються:

Аукціони - найчастіше використовуються для продажу унікальних, коштовних речей;

Біржі - $є$ популярними при реалізації простих товарів, що $\epsilon$ дуже розповсюдженими. Особливістю в даному випадку є коливання ціни на товари.

Інтернет-каталоги - використовуються для реалізації простих, недорогих товарів із стабільною ціною.

Вибір майданчику залежить від специфіки компанії. Іноді реалізація здійснюється й іншими способами, які є менш популярними, проте дуже ефективними в конкретному випадку.

Модель В2С для споживача є більш розповсюдженою і вона має на увазі здійснення угоди між компанією та кінцевим споживачем напряму. Завдяки такій моделі $\epsilon$ можливим реалізовувати будь-який товар: книги, техніку, програмне забезпечення, продукти харчування тощо. Дуже часто при таких видах угод покупці та продавці знаходяться в різних країнах, тобто угоди носять міжнародний характер.

Купівля товарів таким способом підходить не всім споживачам, тому що відсутня можливість побачити товар в реальності, доторкнутися і т. д., однак вона гарантує придбання товару за зниженою ціною, тому що відсутня необхідність орендувати приміщення та витрачати кошту на заробітну плату продавцям.

Модель С2С являє собою угоду між особами, які не пов'язані підприємницькою діяльністю. Це фактично торгові майданчики, про які ми детально говорили у попередніх дослідженнях. На таких майданчиках пропонується як нова продукція, так і та, що вже була у використанні, або товари, виготовлені власноруч. Обсяги торгівлі тут є меншими, ніж при двох попередніх моделях, тому що вибір пропонованих товарів $\epsilon$ незначним.

Модель С2В спеціалізується на певній групі проектів, зокрема на краудсорсінзі. Сутністю такої моделі $є$ те, що будь-хто (не підприємець) може викласти свої роботи на таких майданчиках, і компанії, які можуть бути зацікавлені в таких роботах, мають можливість побачити та обрати будь-яку, наприклад, картину або нетривіальне фото і т. п. Компанії можуть купувати такі ексклюзивні товари для створення власного іміджу або бренду. Іноді такі роботи виконуються за персональними замовленнями.

Бізнес-адміністрування або В2А має на увазі Інтернет-транзакції між бізнесом та державними установами. Сюди належать фіскальні операції, соціальне забезпечення, передавання податкових та юридичних документів. Така модель часто потребує наявності електронного підпису, за допомогою якого керівник може підписувати значний об’єм документів. Також він стає учасником державних аукціонів. 
Модель С2А має на увазі здійснення транзакцій від імені фізичної особи із певною державною установою. В даному випадку мова може йти про подання електронних декларацій, сплата соціальних платежів або медичних послуг.

Такий спосіб є дуже зручним та дозволяє економити час на чергах та очікуванні.

Отже, електронна комерція - це дуже зручний, сучасний спосіб здійснення угод між компаніями та споживачами. Учасниками таких угод можуть бути як підприємці та компанії, так і пересічні громадяни. При цьому для здійснення угоди необхідні дві сторони: продавець та покупець. Так, модель В2В $є$ оптовим майданчиком, де компанії можуть придбати товар на вигідних умовах, а потім продати його кінцевому споживачу. В свою чергу, В2С є класичною Інтернет-торгівлею, навіть, якщо це доставка із кафе або відомого брендового магазину.

Решта моделей $є$ не настільки розповсюдженими, тому що мають менші прибутки i не можуть охопити достатньо широку аудиторію, однак вони досить успішно функціонують в умовах сучасного ринку. Також є моделі, про які йшла мова вище, де одним із учасників транзакцій виступають державні органи влади.

Далі пропонуємо декілька практичних порад щодо ведення бізнесу у галузі електронної комерції.

Отже, в першу чергу, варто подумати не лише про яскравий сайт, він має бути зручним та функціональним. Споживачі повинні дуже легко в ньому орієнтуватись, в протилежному випадку вони дуже швидко вийдуть 3 нього та перейдуть на сайти конкурентів.

Вчасно та з постійною повторюваністю модернізуйте свій сайт, тому що помилки, які, наприклад, виникають при загрузці сторінок, можуть відштовхувати споживачів.

Інформацію про товари викладайте в простому, доступному стилі мовлення, тому при виникненні питань споживачі можуть переходити на інші ресурси, не повертаючись при цьому.

Продумайте про зручність здійснення замовлень. Дуже часто клієнти відмовляються від здійснення купівлі через незрозумілі останні сторінки, де безпосередньо вже робиться замовлення.

Таким чином, бачимо, що створення презентабельного сайту та контенту потребує вкладення коштів, тільки в такому випадку може бути створений прибутковий електронний проект. Стати успішним в даній галузі без залучення професіоналів ззовні $\epsilon$ практично неможливим. В протилежному випадку є ризик втрати значних коштів та часу, при чому сам проект також може бути втраченим на самому початковому етапі. 3 іншого боку, продуманий, виважений підхід дозволить вийти на новий рівень та значно збільшити прибутки.

Висновки. Проведене дослідження дозволяє зробити такі висновки. Аналіз сучасних напрямків досліджень свідчить про те, що на сьогодні одним із потужних стимулів розвитку глобальної економіки $є$ електронна комерція, яка на сьогоднішній день дуже активно розвивається та проникає в усі сфери життя.

Нами проведено аналіз наукових підходів до тлумачення терміну електронної комерції, однак визначено, що загально визнаний концепт відсутній. Резюмовано основні риси електронної комерції, зокрема це: використання електронних платіжних систем у якості аналогу реальних грошових коштів; здійснення угод завдяки використанню сучасних інформаційних технологій; однотипність операцій та можливість вимірів та проведення аудиту провайдером або третьою організацією; права власності та активи зберігаються як у традиційній, так i електронній формах. Структуровано бар'єри для розвитку електронної комерції в Україні: обмежений доступ 
до мережі Інтернет, особливо жителів сільської місцевості; перенасиченість Інтернетмагазинів зайвою інформацією, що провокує втрату потенційних покупців; недостатньо високий рівень освіченості фахівців, які працюють в мережі Інтернет (зокрема відсутність спеціальних знань, необхідних саме для даної галузі).

Визначено, що найбільшими ринками електронної комерції в 2020 році стали ринки Китаю та США із обсягом 672 та 340 млрд. дол. відповідно. Розраховано прогноз динаміки світового ринку електронної комерції до 2030 року, який демонструє стійку тенденцію зростання. На останок, нами представлено практичні поради щодо ведення бізнесу у галузі електронної комерції.

\section{СПИСОК ВИКОРИСТАНИХ ДЖЕРЕЛ}

1. Козье Д. Электронная коммерция. М.: Русская редакция, 1999. 288 с.

2. Место электронной коммерции в подготовке выпускников вуза по специальности “Комерческая деятельность". URL: https://www.elibrary.ru/item.asp?id=24660908.

3. Кобелев О.А. Электронная коммерция: учеб. Пособие. Под ред. проф. С.В. Пирогова. 2-е изд., перераб. и доп. М., 2003.

4. Тимакова А.А., Плюснина Л.К. Использование Е-commerce в рамках развития бренда. URL: https://www.elibrary.ru/item.asp?id=44418955.

5. Электронная коммерция: Учебное пособие. Под ред. С.В. Пирогова - 2-е изд., перераб. и доп. 2010. 684 с.

6. Калужский М.Л. Электронная коммерция: маркетинговые сети и инфраструктура рынка. Москва: Экономика, 2014. 328c.

7. Ковалев С., Ковалев В. Секреты успешных предприятий: бизнес-процессы и организационная структура. М.: БИТЕК, 2012. 498 с.

8. Быстрова Н.В., Хижная А.В., Мазунова А.А., Парадеева И.Н. Имидж организации как фактор повышения ее конкурентоспособности. Международный журнал прикладных и фундаментальных исследований. 2017. № 8-2. С. 321-324.

9. Электронная коммерция: что это такое, виды, примеры, использование в бизнесе. URL: $\quad$ https://www.cleverence.ru/articles/elektronnaya-kommertsiya/elektronnayakommertsiya-chto-eto-takoe-vidy-primery-ispolzovanie-v-biznese/.

10. Global E-Commerce Industry 2021-2024. URL: https://www.reportlinker.com/reportsummary/E-Commerce/160142/Global-E-Commerce-Industry.html.

\section{REFERENCES}

1. Kozie D. Elektronnaia kommercia [E-commerce]. M. Russkaia redaktsia, 1999. 288 p.

2. Mesto elektronnoi kommertsii v podgotovke vypusknikov vuza po spetsialnosti «Kommercheskaia deyatelnost» [The place of e-commerce in training graduates on specialty «Commerce activity». URL: https://www.elibrary.ru/item.asp?id=24660908.

3. Kobelev O.A. Elektronnaia kommertsia [E-commerce]. M. 2003.

4. Timakova A.A., Plyusnina L.K. Ispolzovanie E-commerce v ramkah razvitia brenda [Ecommerce using in the context of brand developing]. URL: https://www.elibrary.ru/item.asp?id=44418955.

5. Elektronnaya kommertsia [E-commerce]. C.V. Pirogov. 2010. 684 p.

6. Kaluzhskii M.L. Elektronnaia kommertsia: marketingovye seti i infrastructura rynka [Ecommerce: marketing networks and market infrastructure]. M.: Ekonomika, 2014. 328 p.

7. Kovalev C., Kovalev V. Sekrety uspeshnyh predpriyatii: bizness-protsesy i organizatsionnaya structura [Secrets of successful enterprises: business-proccesses and organizational structure]. M.: Bitek, 2012. 498 p. 
8. Bystrova N.V., Hizhnaia A.V., Mazunova A.A., Paradeeva I.N. Imidzh organizatsii kak faktor povysheniia ee konkurentosposobnosti [Organization image as a factor of improving its competitiveness]. International journal of applied and fundamental research. 2017. № 8-2. P. 321-324.

9. Elektronnaia commertsia: chto eto takoe, vidy, primery, ispolzovanie $\mathrm{v}$ biznese [Ecommerce: what it is, patterns, using in business]. URL: https://www.cleverence.ru/articles/elektronnaya-kommertsiya/elektronnaya-kommertsiyachto-eto-takoe-vidy-primery-ispolzovanie-v-biznese/.

10. Global E-Commerce Industry 2021-2024. URL: https://www.reportlinker.com/reportsummary/E-Commerce/160142/Global-E-Commerce-Industry.html.

\section{Лимарь В.В.}

\section{ЭЛЕКТРОННАЯ КОММЕРЦИЯ В КОНТЕКСТЕ РАЗВИТИЯ МЕЖДУНАРОДНОГО РЕКЛАМНОГО МЕНЕДЖМЕНТА}

В статье основательно проанализированы научные подходы к пониманию концепта электронной коммерции, проведен анализ тенденций развития мирового рынка электронной коммерции и представлены практические советы относительно развития собственного бизнеса в данной сфере. Резюмированы основные черты электронной коммериии, а именно: использование электронных платежных систем в качестве аналога реальных денежных средств; осуществление соглатений благодаря использованию современных информачионных технологий; однотипность операций и возможность измерений и проведения аудита провайдером или третьей организацией; права собственности и активы хранятся как в традииионной, так и электронной формах. Структурированы барьеры, препятствующче развитию электронной коммериии в Украине: ограниченный доступ к сети Интернет, особенно жителей сельской местности; перенасыщенность Интернет-магазинов лишней информацией, которая провочирует потерю потенциальных покупателей; недостаточно высокий уровень образованности специалистов, которые работают в сети Интернет (в частности отсутствие специальных знаний, необходимых именно для данной отрасли). Рассчитан прогноз динамики мирового рынка электронной коммерции до 2030 года, который демонстрирует устойчивую тенденцию роста. Представлены практические советы относительно ведения бизнеса в отрасли электронной коммерции.

Ключевые слова: электронная коммериия, Интернет-магазин, электронные платежные cuстемы, потенциальные покупатели, контент, глобальная экономика.

\section{Lymar \\ E-COMMERCE IN THE CONTEXT OF INTERNATIONAL ADVERTISING MANAGEMENT DEVELOPMENT}

The paper is devoted to the analysis of the scientific approaches to e-commerce concept understanding; it was made the analysis of the trends of modern e-commerce market development and there were given the practical tips concerning the own business development in this sphere. There were structured the main features of ecommerce, particularly: electronic payment systems using as the analogue of real money; making agreement thank to ICT; operations uniformity and possibility to do audit by provider or another organization; property rights and assets are kept as in the traditional form and electronic one.

The barriers to the development of electronic commerce in Ukraine were structured: limit access to the Internet, especially villagers; Internet-shops oversaturation by extra information what provokes potential customers loosing; low level of education of staff who work in the Internet (in particular, the lack of special knowledge required for this sphere). It was calculated the prognosis of the dynamics of e-commerce international market to 2030, which presents the stable growth. There were presented practical tips how to do business in the sphere of e-commerce. economy.

Key words: e-commerce, Internet-shop, electronic payment system, potential customers, content, global 